\title{
THE "NO PROPERTY" PROBLEM: UNDERSTANDING POVERTY BY UNDERSTANDING WEALTH
}

\author{
Jane B. Baron*
}

ReCKONING WITH HoMELESSNESS. By Kim Hopper. Ithaca: Cornell University Press. 2003. Pp. x, 271. \$19.95.

Could it be that understanding homelessness and poverty is less a function of understanding the homeless and the poor than of understanding how the wealthy come to ignore and tolerate them? This is one of the more intriguing suggestions of anthropologist Kim Hopper's Reckoning with Homelessness, ${ }^{1}$ and it echoes claims made by lawyers who, like Hopper, have spent much of their careers advocating on behalf of the homeless. ${ }^{2}$ While Hopper's new book is first and foremost a work of anthropology, ${ }^{3}$ its structure strongly parallels recent work by legal scholars who have sought to assess the effects of litigation and lobbying efforts dedicated to homelessness. ${ }^{4}$ Looking back on his own twenty-five years of work on behalf of the homeless, Hopper laments that his and his colleagues' detailed ethnographies of the lives of homeless people provided "vivid documentation and lively analyses, but at the cost of ensuring that the

* Professor of Law, Temple University Beasley School of Law. B.A. 1975, J.D. 1978, Harvard. - Ed. Thanks to Theresa Glennon, Richard K. Greenstein, and Jeffrey L. Dunoff for helpful comments. Thanks also to Noah AnStraus for capable research assistance. This project was supported by a summer research grant from Temple University Beasley School of Law.

1. Kim Hopper is a Research Scientist at the Nathan S. Kline Institute for Psychiatric Research and Lecturer at the Columbia University schools of Public Health and Law.

2. See, e.g., Gary Blasi, And We Are Not Seen: Ideological and Political Barriers to Understanding Homelessness, 37 AM. BEHAV. SCIENTIST 563 (1994) [hereinafter Blasi, And We Are Not Seen]. This convergence is probably neither ironic nor surprising in light of the fact that Hopper and Blasi were active in homeless advocacy projects over the same period of time, and are aware of, and frequently cite, each other's writings.

3. Hopper describes his particular style as "no name anthropology," which he distinguishes from "the fireworks of postmodernism." P. 9.

4. See Wes Daniels, 'Derelicts,' Recurring Misfortune, Economic Hard Times and Lifestyle Choices: Judicial Images of Homeless Litigants and Implications for Legal Advocates, 45 BUFF. L. REV. 687 (1997); Maria Foscarinis, Homelessness and Human Rights: Towards an Integrated Strategy, 19 ST. LOUIS U. PUB. L. REV. 327 (2000) [hereinafter Foscarinis, Homelessness and Human Rights]; Jonathan L. Hafetz, Homeless Legal Advocacy: New Challenges and Directions for the Future, 30 FORDHAM URB. L.J. 1215 (2003); Lucie E. White, Representing 'The Real Deal,' 45 U. MIAMI L. REV. 271 (1991). 
product could be safely ignored" (p. 209). The legal advocates' assessment of their efforts is even more downbeat; they fear that their own litigation strategies - even when successful - may have aggravated rather than resolved the problems faced by their clients. ${ }^{5}$

We know a lot more about homelessness today than we knew in the 1980s, when homelessness began to be understood as a crisis. Indeed, studying the homeless has become a veritable industry. ${ }^{6}$ One thing on which pretty much all scholars agree is that homelessness and poverty are strongly related. Homeless people may or may not be alcoholics, mentally ill, substance abusers, single, or male, but they are, all of them, poor. ${ }^{7}$ As historians of welfare have repeatedly shown, poverty alone has not reliably produced sympathy in the hearts and minds of the American public and its legislators; indeed, the poor have as often been regarded with hostility as with compassion or even acceptance. ${ }^{8}$ But at least for a time, the plight of the homeless poor did evoke sympathy and compassion, ${ }^{9}$ and substantial social resources -

5. See, e.g., Foscarinis, Homelessness and Human Rights, supra note 4, at 328 (describing "paradoxical remedies, misguided legal and policy debates, and unclear directions for the future"); White, supra note 4, at 274 (inquiring whether images of the homeless used to draw attention to the low-income housing crisis "might not play upon 'unconscious' racism to mobilize sympathy for the poor").

6. See Gary L. Blasi, Social Policy and Social Science Research on Homelessness, $46 \mathrm{~J}$. SOC. Issues 207, 207 (1990) [hereinafter Blasi, Social Policy and Social Science] (describing "an enormous amount of research on homelessness"); see also MARTHA BURT ET AL., HELPING AMERICA'S HOMELESS: EMERGENCY SHELTER OR AFFORDABLE HOUSING? (2001) [hereinafter BURT ET AL., HELPING AMERICA'S HOMELESS] (reporting and analyzing data on the numbers and demographic characteristics of the homeless); Lois $\mathrm{M}$. Takahashi, A Decade of Understanding Homelessness in the USA: From Characterization to Representation, 20 PROGRESS IN HUMAN GEOGRAPH Y 291 (1996) (reviewing literature on homelessness from the decade 1986-96). Hopper's bibliography runs in excess of twentyfive pages.

7. See, e.g., BURT ET AL., HelPING AMERICA's Homeless, supra note 6, at 93 (citing "extreme poverty" as the "common denominator of homelessness").

8. See, e.g., Joel F. Handler \& Yeheskel Hasenfeld, We the PoOR PeOPle: WORK, POVERTY, AND WELFARE (1997) [hereinafter HANDLER \& HASENFELD, WE THE Poor People]; Michael B. Katz, The Undeserving POOR: From the War on POVERTY TO THE WAR ON WELFARE (1989).

9. How long a time is open to question. Whether due to "compassion fatigue" or other factors, the sympathy was not boundless, as evidenced by many jurisdictions' enactment of ordinances designed to move the homeless out of places they tended to congregate, such as parks, or otherwise to criminalize behavior associated with homelessness, such as panhandling. Cases testing the legality of such policies include Gresham v. Peterson, 225 F.3d 899 (7th Cir. 2000) (holding that a statue banning all panhandling in certain areas, banning all panhandling at night, and banning "aggressive panhandling" in all locations throughout the city was a content-neutral time, place, and manner restriction and thus constitutional); McFarlin v. District of Columbia, 681 A.2d 440 (D.C. Ct. App. 1996) (holding that a statute banning begging near subway stops was a reasonable regulation of begging and therefore constitutional); Tobe v. City of Santa Ana, 892 P.2d 1145 (Cal. 1995) (upholding an ordinance that made it a crime to camp and store belongings in public parks). 
ranging from shelter beds to health care - were mobilized to help them. ${ }^{10}$

Part of what enabled that sympathy was the work of Hopper and his fellow anthropologists, who struggled to themselves understand the lives of the homeless, and then to convey those lives to the rest of us. As Hopper puts it, "impelled by an elemental moralism, we set about telling the story of homelessness in all its unsettling specificity .... We gave them names, showed you their faces, ransacked our fieldnotes for arias of heartbreaking tragedy and quiet heroism" (p. 193). Another part of what enabled sympathy for the homeless was the legal strategy, partly parasitic on the ethnographies, that traded on the "involuntariness" of homelessness. How, advocates argued, could those who "have no realistic choice but to live in public places" be punished for acts such as sleeping in parks? ${ }^{11}$

What seemed like success at the time, or at least progress, now appears less rosy, Hopper argues. In his pessimism about advocacy for the homeless, Hopper is joined by legal colleagues who wonder about hidden costs of apparent victories. First, homelessness has been approached less as a long-term problem of housing or employment than as a short-term emergency that can be remedied by more shelter beds and mission meals. ${ }^{12}$ Second, advocates have sought to differentiate the homeless, to define them as having unique problems and particular (albeit ultimately logical) ways of coping with those problems. This strategy has "orphaned" the homeless from the rest of

10. At the center of many of these efforts stands a noteworthy piece of federal legislation, the Stewart B. McKinney Homeless Assistance Act, Pub. L. No. 100-77, 101 Stat. 482 (1987) (codified as amended at 42 U.S.C. § 11301-11435. (2000) (subsequently renamed the McKinney-Vento Homeless Assistance Act)). For summaries of the act, see Maria Foscarinis, The Federal Response: The Stewart B. McKinney Homeless Assistance Act, in HOMELESSNESS IN AMERICA 160 (Jim Baumohl ed., 1996), and Martha R. Burt, Chronic Homelessness: Emergence of a Public Policy, 30 FORDHAM URB. L.J. 1267 (2003) [hereinafter Burt, Chronic Homelessness].

11. Pottinger v. City of Miami, 810 F. Supp. 1551, 1563 (S.D. Fla. 1992). Pottinger held that Miami's "practice of arresting homeless individuals for harmless, involuntary conduct they are forced to perform in public" violated the plaintiffs' rights to due process and travel, as well as their rights under the Fourth and Eighth Amendments. Id. at 1584. On appeal, the case was remanded, Pottinger v. City of Miami, 40 F.3d 1155 (11th Cir. 1994), and ultimately settled. Pottinger was probably the high water mark of "free to be homeless" cases. Its holdings were rejected in, inter alia, Davison v. City of Tucson, 924 F. Supp. 989 (D. Ariz. 1996) and Tobe v. City of Santa Ana, 892 P.2d 1145 (Cal. 1995). On the connection between freedom and public spaces in the life of the homeless, see Jeremy Waldron, Homelessness and the Issue of Freedom, 39 UCLA L. REV. 295 (1991).

12. See, e.g., White, supra note 4, at 296 (describing as one of the costs of advocates' rhetoric about homelessness "the skewing of low-income housing policy away from permanent solutions and toward ad hoc crisis intervention"); see also KENNETH L. KUSMER, DOWN AND OUT, ON THE ROAD: THE HOMELESS IN AMERICAN HISTORY 245 (2002) (arguing that programs for the homeless in the 1980s and 1990s focused on emergency provision of shelter and food, and not "the kind of structural reforms that would help lift people out of homelessness permanently - affordable housing, job training, less penurious welfare benefits, and a decent minimum wage"). 
the poor (p. 198-99). Finally, the legal and anthropological approaches both somehow left race out of the picture - a disconcerting omission given the overrepresentation of African Americans among the homeless. ${ }^{13}$

One of Hopper's main goals in his book is to "take stock" (p. 193) of these phenomena - which he ultimately regards as advocacy failures. Though Reckoning With Homelessness has a retrospective cast, Hopper's reflections on what has and what has not "worked" have implications for future work on behalf of the homeless. And we will need to do some thinking. Homelessness has by no means gone away ${ }^{14}$ and, if the front pages of our nation's major newspapers are any indication, homelessness seems to be on its way to being a "crisis" again. ${ }^{15}$

In this Review, I take up the themes in Hopper's book that bear most on how we are likely to confront - or maybe avoid confronting - this new crisis. Part I considers how the social science world has studied homelessness - both its generation of "facts" about homelessness and its framing of the debate over whether individual or structural forces cause homelessness. As Reckoning with Homelessness reveals, this debate continues to this day to structure much thinking about homelessness. Yet, on reflection, it is not entirely obvious why those terms of debate are still so powerful. The line between the "individual" and the "structural" is extremely unstable, and as Hopper himself (sometimes) recognizes, the rhetoric of individual responsibility can easily backfire.

Part II considers how the individual/structural debate has interacted with, or, as Hopper argues, failed to interact with, other important debates about poverty and race. Here, Hopper's assessment

13. P. 156 ("Throughout the 1980s, researchers consistently found that black males (and especially young black men) were overrepresented among local [New York] homeless populations.").

14. The survey described in BURT ET AL., HELPING AMERICA's HOMELESS, supra note 6 , at 50 , estimated that perhaps as much as 1.3 percent of the nation's population was homeless at some time during the year beginning February 1996. As explained infra text accompanying notes 19-21, counting methodologies are highly variable and most counts are contested as too high or too low. Burt devotes substantial attention to the problems of counting. See BURT ET AL., HELPING AMERICA's HOMELESS, supra note 6, at 23-46.

15. Andrea Elliott, Record Number of Homeless, But City Says It's Prepared, N.Y. Times, July 2, 2003, at B1; Charlie LeDuff, In Los Angeles, Skid Row Resists an Upgrade, N.Y. Times, July 15, 2003, at A1; Ilene Lelchuk, Judge Says Counties, Not Voters, Have Power to Determine Welfare Levels for Poor, S.F. CHRON., May 9, 2003, at A1; Emily Sweeney, Outlook for 67 Families Uncertain; Shelters at Fernald May be Closed, BOSTON GLOBE, July 6, 2003, at 1 . A recent survey by The United States Conference of Mayors confirms these newspaper accounts. U.S. CONFERENCE OF MAYORS, A STATUS REPORT ON HUNGER AND HOMELESSNESS IN AMERICA'S CITIES 7 (2002) (Based on a survey of twentyfive cities, "during the past year requests for emergency shelter increased in the survey cities by an average of 19 percent .... Requests for shelter by homeless families alone increased by 20 percent."), available at http://usmayors.org/uscm/hungersurvey/2002/onlinereport/ HungerAndHomelessReport2002.pdf (last visited Sept. 25, 2004). 
tracks those of legal advocates who litigated on behalf of the homeless. These assessments together raise important questions about why alliances between "the poor" and "the homeless" were never explicitly drawn. Hopper and legal analysts agree that race has figured far less than it should have in debates about homelessness, but they are not entirely clear about why that omission has been problematic.

Part III considers Hopper's provocative indictment of his own studies of the attitudes and coping mechanisms of the homeless poor. How could these ethnographies be "safely ignored," as Hopper asserts? More particularly, I take up Hopper's provocative suggestion, also echoed by legal advocates, that only by studying wealth - and its reaction to homelessness - can we understand poverty. Hopper writes:

[I]t no longer suffices (if it ever did) to ask what it is about the homeless poor that accounts for their dispossession. One must also ask what it is about "the rest of us" that has learned to ignore, then tolerate, only to grow weary of, and now seeks to banish from sight the ugly evidence of a social order gone badly awry. ${ }^{16}$

Without dismissing the potential importance of studying the wealthy and their attitudes, ${ }^{17}$ this Review suggests that at least part of what confounds understanding of homelessness is its embodiment of a difficult-to-fathom state of what might be called "no property." Ethnographies focus on who the homeless are, but the defining attribute of homelessness consists of what those people do not have. It is not easy to study a negative or lack, and far easier to study what it is a lack of. In this sense, my proposal is consistent with and parallels the conclusions - implicit in Hopper's work and explicit elsewhere that to understand homelessness we must first better understand wealth. But in my view it will not be enough to stop with the psychological or cognitive defense mechanisms that allow those with property to ignore or even disdain those who lack it. For "no property" is not only a lack, but a legal and social state of being. In this legal state, one can plausibly seek rights to sleep outdoors and panhandle aggressively (rights, that is, to be homeless effectively) but

16. P. 214. In Reckoning with Homelessness, Hopper does not actually specify what "we" do to keep the homeless at bay. He proposes instead that we study how the problem of housing "was solved (or prevented) in the past; what about those practices or policies might be resurrected and retooled to the specifications of the present; and what newly fashioned remedies might be needed ...." P. 215.

17. At least one influential legal scholar proposes that we study cognitive responses to homelessness and develop litigation strategies that take account of them. Gary Blasi, Advocacy and Attribution: Shaping and Responding to Perceptions of the Causes of Homelessness, 19 ST. LoUIS U. PUB. L. REV, 207 (2000) [hereinafter Blasi, Advocacy and Attribution]. On the role of cognitive theory more generally in lawyering, see Gary Blasi, What Lawyers Know: Lawyering Expertise, Cognitive Science, and the Functions of Theory, 45 J. LEG AL EDUC. 313 (1995). 
one is not entitled to housing or public welfare benefits (rights, that is, to have property). To understand homelessness, we must at least confront the complexities of this new "no property" category.

\section{SOCIAL SCIENCE AND THE STUDY OF HOMELESSNESS}

Reckoning with Homelessness does not purport to summarize the massive amount of social science research that has been conducted on homelessness over the last twenty years. ${ }^{18}$ Yet Hopper's descriptions of and reflections on his own work touch on some of the important recurring methodological issues that arise in studies of the homeless, and his conclusions echo themes that run through a wide array of otherwise disparate social science research. Because these themes continue to characterize debates about homelessness, it is worth describing them, even if one has to paint in broad strokes.

A huge issue for homelessness research has been the question of how many homeless people there actually are. ${ }^{19}$ The quantification problem partly derives from a secondary methodological issue: How should homelessness be defined? ${ }^{20}$ Are people "homeless" only if they are using a shelter today? What about people doubled up with friends and family? How about people who sleep in flophouses or hotels three weeks of the month, until benefit checks run out, and then are without shelter for the week until the next check arrives? How about people who are housed today, but who have lived in shelters for the previous six months? These methodological questions are not trivial: if there

18. And I do not here try my own hand at such a summary. One useful overview is Heidi Sommer, Homelessness in Urban America: A Review of the Literature (2000), at www.igs. berkeley.edu/events/homeless/NewHomelessnessBook1.pdf (last visited Sept. 23, 2003).

19. This question initially arose after activist Mitch Snyder testified before Congress in 1983 that three million people were currently homeless - a number on which the press feasted, but which was almost immediately contested. See S. Anna Kondratas, A Strategy for Helping America's Homeless, in HOUSING THE HOMELESS 144 (Jon Erickson \& Charles Wilhelm eds., 1986) (summarizing the controversy and attacking Snyder's estimate). But the number issue quite likely would have arisen anyway, in response to a general perception in the mid-1980s that the number of homeless people was growing dangerously high. See MARTHA R. BURT, OVER THE EDGE: THE GROWTH OF HOMELESSNESS IN THE 1980S 3 (1992) [hereinafter BURT, OVER THE EDGE] (describing an annual rate of increase in homelessness of about twenty-two percent for the three years between 1984 and 1987). Almost every serious study of the homeless begins with a discussion of the difficulty of counting them. See, e.g., GregG BARAK, Gimme SHelter: A Social History OF HOMELESSNESS IN CONTEMPORARY AMERICA 21-33 (1991); BURT ET AL., HELPING AMERICA'S HOMELESS, supra note 6, at 23-53; CHRISTOPHER JENCKS, THE HOMELESS 1-20 (1994); PETER H. ROSSI, DOWN AND OUT IN AMERICA: THE ORIGINS OF HOMELESSNESS 45-81 (1989); JAMES D. WRIGHT, ET AL., Beside THE GoldEN DOOR: POLICY, POlitics, AND THE HOMELESS 53-63 (1998); Martha R. Burt, Homelessness: Definitions and Counts, in HOMELESSNESS IN AMERICA 15 (Jim Baumohl ed., 1996) [hereinafter Burt, Homelessness: Definitions and Counts].

20. See, e.g., Brendan O'Flaherty, MAKING RoOM: THE Economics of HOMELESSNESS 9-19 (1996); Burt, Homelessness: Definitions and Counts, supra note 19, at 16-17; RosSI, supra note 19, at 47-48. 
are not "a lot" of homeless people (and of course there is controversy, too, about what "a lot" might be), then perhaps there is no serious social problem requiring public response. ${ }^{21}$

But even if the number of homeless is large, there is another question that determines how important the problem is: Who are the homeless? Again, study after study of the homeless attempts to analyze the demographics of the homeless population. ${ }^{22}$ Are they single? Are they families? Male? Female? Black? Educated? Employed? Drug addicted? Mentally ill? And in what proportions? To some extent, these are quantitative questions, answered by collecting and then crunching data. ${ }^{23}$ Numbers, however, do not fully capture who the homeless are. Thus, sociologists and anthropologists have attempted to describe the homeless by learning enough about their lives to tell their stories, or to convey homeless persons' own descriptions of how they live their lives. ${ }^{24}$

Hopper's own experience straddles the line between demography and ethnography. One chapter of Reckoning with Homelessness describes a research project, conducted under the auspices of the New York State Office of Mental Health, to design "a 'brief ethnographic' inquiry into some of the informal shelter devised or appropriated by the homeless poor in public spaces" (p. 132). The purpose of the inquiry was to improve efforts by the Census Bureau to enumerate the shelter- and nonshelter-residing homeless population in $1990 .{ }^{25}$ The study concludes with six separate technical recommendations for modifying the procedures in future census counts (pp. 143-45). But its

21. See Robert C. Ellickson, The Homelessness Muddle, 99 PUB. INT. 45, 58 (1990) (asserting that advocates for the homeless, inter alia, "misled the public by exaggerating the size of the homeless population," and that such distortions "may result in ill-advised policies"); Kondratas, supra note 19, at 148 (arguing that if the U.S. is not "swamped with millions of homeless Americans, then ... there is little justification for asking Washington to intervene"). One could argue, of course, that any number of homeless people is too many and that all homelessness warrants a public response.

22. See, e.g., RossI, supra note 19, at 117-41; BURT ET AL., HELPING AMERICA's HOMELESS, supra note 6, passim.

23. Important surveys include those conducted by ROSSI, supra note 19, and BURT ET AL., HELPING AMERICA'S HOMELESS, supra note 6. Other important surveys include the census counts of 1990 and 2000, and a HUD count published in 1984. U.S. DEP'T OF Housing and URban DeV., OfFICE OF POLICY DEV. AND RESEARCH, A RePORT TO THE SECRET ARY ON THE HOMELESS AND EMERGENCY SHELTERS (1984).

24. See, e.g., Ellen Baxter \& Kim Hopper, Private lives/Public Spaces: HOMElESS AdUltS ON THE STREETS OF NEW YORK CITY (1981); Elliot LieBOW, TELL THEM WHO I AM: THE Lives OF HOMELESS WOMEN (1993); DAVID A. SNOW \& LEON ANDERSON, DOWN ON THeIR LUCK: A STUDY OF HOMELESS STREeT PEOPLE (1993).

25. As Hopper explains, the Census Bureau conducted counts of both street and shelter homeless in several cities on one night ("S Night") in 1990. P. 131. The counts were widely criticized for bad methods and faulty conclusions. P. 135. Hopper asserts that in response to various "research-based criticisms," the Census Bureau "substantially revised its procedures for Census 2000.” P. 145. 
other findings - those that seem closer to Hopper's heart - do not directly bear on numbers, but on quality of life issues:

The most salient lesson to be drawn from this brief study can be put simply: "The street" is not now, if it ever was, synonymous with anarchy. Even here, distinctive rules and routines prevail .... "Regulars" [among the homeless at the sites visited] recounted (at times in painstaking detail) the working "rules" of that space, the schedules and addresses of local soup kitchens, the locations of prized out-of-the-way havens, the names of potential sources of aid.... Beat cops, security guards, and token-booth clerks at certain sites awakened occupants in time for work each day. (p. 136)

Notice here how the homeless are naturalized; in having and being subject to rules in their apparently chaotic life, they are more "like" us. Hopper says as much: "Much as the cadre of street dwellers impressed the observers as distinctly 'other' - the classic subject of field work - they also met and ... came to know people who could pass for kin or acquaintances" (p. 136).

Why is it important to note that homeless persons are not in all respects and always "distinctly 'other' "? ${ }^{26}$ This question connects to perhaps the most important question asked by social scientists studying the homeless: Why do people become homeless? Is a person's homelessness a function of individual and personal failure, or is it a function of structural forces of which the individual has little or no control ? $^{27}$ To those who see homelessness primarily ${ }^{28}$ in terms of individual responsibility, drug addiction, substance abuse, and mental illness are the factors most frequently cited to explain homelessness. ${ }^{29}$ Those who see homelessness primarily in terms of structural factors most frequently cite lack of affordable housing, falling real wages and

26. One work often noted for the argument that the homeless are in some sense just ordinary people like "us" is JONATHAN KOZOL, RACHEL AND HER CHILDREN (1988). Robert Ellickson has argued that homeless people are not in fact ordinary, see Ellickson, supra note 21, at 58, and Lucie White has argued that the images Kozol presents reinforce unconscious racism by "evok[ing] concern for the poor by appealing to race and class privilege, to the desire that is engineered among all groups in this society to be 'white.'" White, supra note 4, at 305.

27. This debate is ubiquitous in the literature. For an overview of the debate, see Paul Koegel et al., The Causes of Homelessness, in HOMELESSNESS IN AMERICA 24 (Jim Baumohl ed., 1996). For poles in the debate, compare ALICE S. BAUM \& DONALD W. BURNS, A NATION in Denial: The TRUTh About Homelessness (1993) (emphasizing individual factors), with WRIGHT ET AL., supra note 19, at 2-7 (emphasi zing structural factors).

28. Almost no one is purely in one camp or the other. That is, most commentators attributing homelessness primarily to individual factors take at least some account of structural factors, and vice versa.

29. See, e.g., BAUM \& BURNES, supra note 27; Ellickson, supra note 21; see also JENCKS, supra note 19 (adding the crack epidemic and reductions in family ties); RICHARD W. WHITE, JR., RUDE AWAKENINGS: WhAT THE HOMELESSNESS CRISIS TELlS US (1992) (describing the failure of the homeless to seek jobs). 
employment opportunities, and reductions in government benefits. ${ }^{30}$ The most measured analysts combine the structural and individual explanations in to what might be called the "vulnerability synthesis," in which personal factors are understood to interact with structural forces in a way that can push someone, in Martha Burt's words, "over the edge" in to homelessness:

The trouble begins when very poor people live in cities with very high living costs, and cannot earn enough or receive enough in benefits to cover expenses. In this sense poverty represents a vulnerability, a lower likelihood of being able to cope when the pressure gets too great. It thus resembles serious mental illness, physical handicaps, chemical dependency, or any other vulnerability that reduces one's resilience, and the resilience of one's family and friends. One would be reluctant to say that mental illness causes homelessness, but being mentally ill may well increase the probability that homelessness will result if the person faces a severe crisis.... This is the way I now think of poverty in relation to homelessness. Higher poverty rates certainly make more people vulnerable to homelessness. But without the structural pressures of poorquality jobs, high living costs, pressure from the middle class, and tight housing markets, they would not be homeless. Even without any growth in poverty, increases in these contributing risk factors could easily make more poor people homeless. I think that is what happened in the $1980 \mathrm{~s}^{31}$

30. See., e.g., BARAK, supra note 19; Joel BlaU, THE VISIBLE POOR: HOMELESSNESS IN THE UNITED ST ATES (1992); RosSI, supra note 19; Cushing N. Dolbeare, Housing Policy: A General Consideration, in HOMELESSNESS IN AMERICA 34 (Jim Baumohl ed., 1996); Kim Hopper \& Jill Hamberg, The Making of America's Homeless: From Skid Row to New Poor, 1945-1984, in CR ITICAL PERSPECTIVES ON HOUSING 12 (Rachel G. Bratt et al. eds., 1986); see also CHARLES HOCH \& ROBERT A. SLAYTON, NEW HOMELESS AND OLD: COMMUNITY AND THE SKID ROW HOTEL (1989) (describing the loss of skid row and SRO hotels); JENCKS, supra note 19 (describing changes in policies governing admission and discharge of persons with mental illnesses); WILliAM TUCKER, THE EXCLUDED AMER ICANS: HOMELESSNESS AND HOUSING POLICIES (1990) (discussing exclusionary zoning and rent control).

31. BURT, OVER THE EDGE, supra note 19, at 198. Burt's recent work continues to reflect this thesis:

[T] he key to persistent widespread homelessness in the United States appears to be the persistent and worsening mismatch of housing cost to available household resources. With this mismatch as the structural backdrop, personal vulnerabilities combine and interact to increase the risk that a person will be extremely poor, and also become homeless .... Without the poverty and the affordable housing crisis, the same vulnerabilities would not produce homelessness. With them, it is to some degree a random process that determines which individuals and households will experience the one crisis too many that will push them into homelessness.

BURT ET AL., HELPING AMERICA's HOMELESS, supra note 6, at 322.

Peter Rossi reached roughly the same conclusion as early as 1989:

[A]mong the extremely poor, those with disabilities are the most vulnerable to homelessness. Especially critical are those disabilities that make it difficult for relatives, especially, but also friends, to generously provide shelter and support. In particular, those with chronic mental illness, severe alcoholism, and criminal records do not make good housemates and are eased out from under the protective wing of their relatives and friends. 
As with the question of who the homeless are, the question of why people are homeless is frequently analyzed in statistical terms. Why, for example, if the incidence of drug use and mental illness has not increased in the population at large, should it increase as a percentage of the homeless population? ${ }^{32}$ Can abuse or out-of-home placement be correlated with homelessness? ${ }^{33}$ But here again, in the context of causal factors, there is another strain, typified by Hopper, that seeks to explain the why of homelessness by thick description of homeless people's lives. The longest chapter in Reckoning with Homelessness is "Streets, Shelters, and Flops: An Ethnographic Study of Homeless Men, 1979-82." 34 Using the method of "participant observation" (p. 67), Hopper and his colleagues inquired "(1) how people became homeless in the first place and (2) the nature of public provision for their shelter once officially certified as homeless" (p. 66). Though the questions seem analytically distinct, with only the first bearing on the "why" of homelessness, they connect through the vector of "choice," which bears directly on the individual/structural debate; Hopper's study seeks to determine whether the homeless choose "to fend for

Rossi, supra note 19, at 179.

32. BURT, OVER THE EDGE, supra note 19, at 120.

33. BURT ET AL., HELPING AMERICA'S HOMELESS, supra note 6, at 86-93. Other studies heavy on statistical analysis include O'FLAHERTY, supra note 20, and ROSSI, supra note 19.

34. Pp. 60-116. Throughout the book, Hopper chooses to focus on homeless men, not families. He describes his reasons as follows:

First and foremost is a methodological and archival given: Male gender shaped the terms of access and affiliation in my own ethnographic efforts and dominates the historical record.... Second, since the mid-1980s, the wheel of social opinion has turned inexorably forward once again - focusing on families rather than "unattached" men ... - to the detriment of the men who first gave evidence of the new homelessness.... Finally, this study highlights the situation of men, especially the young African American males who make up the bulk of the shelter population in New York, because this group has proved most vulnerable to the dislocations of deindustrialization.

Id. at 13-14.

Hopper's focus on men is limiting, for, as he recognizes, families are an important segment of the total homeless population. Indeed, "officials estimate that, on average, single men comprise 41 percent of the homeless population, families with children 41 percent, single women 13 percent and unaccompanied minors five percent." U.S. CONFERENCE OF MAYORS, A STATUS REPORT ON HUNGER AND HOMELESSNESS, supra note 15 , at ii. Moreover, there is evidence that the number of homeless families is growing. The Status Report states that "Requests for emergency shelter by homeless families with children increased in 88 percent of survey cities during the year," and that "[a]cross the survey cities, the average increase in request for emergency shelter by homeless families with children was 20 percent." Id. at 47 . On the other hand, there is evidence that "if an y subgroup [of the homeless] is being better served by the system, it is families," whereas "single men and female other clients stand out as the two subgroups having the most marginal relationship with the homeless assistance network." BURT ET AL., HELPING AMERICA'S HOMELESS, supra note 6 , at 74 .

For an ethnographic account focusing on women rather than men, see JEAN Calterone Williams, 'A RoOF OVER MY Head': Homeless WOMEN AND THE SHELTER INDUSTR Y (2003). 
themselves on the street" (p. 67) or are there for some reason beyond their control.

While Hopper acknowledges employment losses, low-cost housing shortages, and dislocations in government-relief programs as major causal forces in twentieth-century homelessness (p. 76), he rejects a "strictly linear view" and finds a wide range of events triggering homelessness among his informants (p. 78). Precipitating events included binge drinking, eviction, deinstitutionalization without follow-up care, and reluctance to overtax family resources (p. 79-84). Hopper ultimately rejects the idea of fitting his findings into a " 'classification' scheme of 'homeless types," " preferring instead to focus on the variety of problem-solving techniques employed by the homeless in response to the many forces that pushed them toward the streets (p. 84).

Hopper's interest in the hidden rationality of the coping strategies homeless men employ on an everyday basis is manifest when he turns directly to the question of why the homeless choose the streets over publicly-available shelters. After detailing his own and his informants' experiences of filth, violence, staff disrespect, and danger at public shelters, he concludes that the street dwellers were not "unwilling" to accept assistance, nor did they suffer from impaired judgment or other pathology - all allegations raised by service providers during the period in question (p. 114). Given the degrading conditions in the shelters, "the city's offer of refuge was a tarnished one" (p. 114), and thus the " 'inability' or 'unwillingness' of many to accept help was a deliberate decision to seek relief on their own terms" (p. 115). Indeed, "the ethnographic picture reconfirmed the 'complicated meanness' that survival on the streets entails," and experiencing the daily round of soup lines, the frustrations of seeking income assistance, and the superior attitude of those who purported to be helping all allowed Hopper to appreciate "the ingenuity and resourcefulness of those who managed despite the odds" (p. 115).

As in Hopper's earlier depiction of the "rules" governing the apparently anarchic life of the homeless, here again he naturalizes the homeless. His investigation of the material conditions in which they live shows that they are not irrational or ungrateful eccentrics. Rather they emerge as rational persons responding as you and I might to circumstances that are insufficiently understood by those who have never experienced anything like them. In declining to use shelters, the homeless are not meaningfully "choosing" the streets; instead they are avoiding the greater of two evils. In their situation, Hopper argues, we would do the same things - if we were resourceful enough to think of them.

In depicting the homeless as ultimately rational actors responding to dysfunctional social conditions, Hopper locates himself among those attributing homelessness primarily to structural rather than 
individual causes. $\mathrm{He}$ is more explicit than most about what might be at stake in the individual/structural debate. "The practical implications" of his study, he writes, "were ... clear: If it could be shown that the chief causes of visible homelessness resided in street denizens themselves, then the direction of public policy would be considerably different from that being pursued in the courts. ${ }^{35}$

Here, in naked terms, is the usually unstated premise of so much of the social science literature: to the extent that homelessness is the product of structural forces, the homeless are not themselves to blame for their plight and, it would seem to follow, government or charitable intervention can legitimately be requested if not expected. Conversely, to the extent that homelessness is caused by personal failure - drug or alcohol addiction, or inability to manage money - the claim for government or charitable assistance must be considerably weaker. Thus, the stakes in interpreting or characterizing the empirical data are considered to be quite high.

Yet it is not clear that these characterizations have the consequences that social scientists such as Hopper attribute to them. If the structural factors in question are "the housing market" or "loss of high paying factory jobs," is it really likely that government especially a Republican dominated government - will be moved to intervene? Many believe that the purpose of government is to facilitate the orderly operation of markets, not to interfere with them. On the other side, some "personal" or "individual" failings have provoked government responses, especially where the problem in question, such as mental illness, renders the afflicted vulnerable to abuse by others. New York State's response to a recent scandal involving the mistreatment of the noninstitutionalized mentally ill living in private "homes" illustrates this phenomenon. ${ }^{36}$

35. P. 67. The court case to which Hopper refers is Callahan v. Carey, a class-action lawsuit which sought to establish that the City of New York had a legal duty to provide shelter to indigent homeless men. Without reaching the merits, the New York Supreme Court issued a consent decree in 1981 that required the City to

provideshelter and board to each homeless man who applies for it provided that (a) the man meets the need standard to qualify for the home relief program established in New York State; or (b) the man by reason to [sic] physical, mental or social dysfunction is in need of temporary shelter.

Callahan v. Carey, No. $42582 / 79$ (N.Y. Sup. Ct.) (Final Judgment By Consent, August 1981), at http://www.coalitionforthehomeless.org (last visited Sept. 23, 2004). The Callahan requirements were extended to women in Eldredge v. Koch, 469 N.Y.S.2d 744 (1983) and to homeless families with children in McCain v. Koch, 517 N.Y.S.2d 918 (1987). For a detailed description of the Callahan litigation, see Bradley R. Haywood, The Right to Shelter as a Fundamental Interest Under the New York State Constitution, 34 COLUM. HUM. RTS. L. REV. 157 (2002).

36. The scandal involved the placement of deinstitutionalized mentally ill persons into nursing homes and other facilities that offered them nothing in the way of treatment and whose conditions may have been more inhumane than the hospitals from which they had been released. Clifford J. Levy, Mentally IIl and Locked Up in New York Nursing Homes, 
But even if it were true that "structural" causes of homelessness were more likely to be addressed than "individual" causes, the line between the structural and the individual is hardly clear. Labor market changes lead (sometimes) to job instability, which in turn leads (sometimes) to episodes of homelessness, which may (sometimes, e.g., where the homeless person in question is a single mother) disrupt children's educational continuity, which in turn leads (sometimes) to behavioral and emotional problems affecting a child's ability to learn, which may (sometimes) lead down the road to problems gaining stable employment. What in this is "structural" and what "individual"?

Since the lines between the "structural," and the "individual" seem so indistinct, and since the political valence of the characterizations seems so questionable, it seems worthwhile to ask why these categories continue to organize thinking about the homeless. One would like to speculate that Hopper's thinking reflects the historical period, principally the 1980 s, during which he was most active - a period in which Ronald Reagan's portrait of the "welfare queen" could capture the public imagination. This hypothesis is, however, too optimistic. As one historian of welfare puts it, "the category 'undeserving poor' has echoed across two centuries; it persists, today, as vividly as a century and a half ago." ${ }^{37}$

Nonetheless, despite the durability of the rhetoric of desert and merit, it is worth considering whether a change in the terms of the debates about the problem of homelessness would be useful in any way. It seems safe to bet that, given current preoccupations with terrorist threats and the proliferation of nuclear, biological, and chemical weapons, we are unlikely soon to see major changes in the resources committed to the problem of homelessness. Thus, debates about homelessness may be less important for what they do than for what they express about our values. To talk about homelessness in terms of the "structural" and the "personal" may not just reflect but also participate in creating notions of desert and merit. ${ }^{38}$ As Hopper is well aware, the discourse of desert has only gotten the homeless so

N.Y. TIMES, Oct. 6, 2002, at A1. The reports prompted an inquiry by the United States Justice Department. Clifford J. Levy, Justice Department to Scrutinize Confinement of Mentally Ill, N.Y. TIMES, Oct. 12, 2002, at B1. The state then prohibited the discharge of psychiatric patients to the private nursing homes exposed in the scandal. Clifford J. Levy, Hospitals Will Stop Sending Mentally III To Nursing Homes, N.Y. TIMES, Oct. 19, 2002, at A1.

37. Michael B. Katz, The PRice of Citizenship: Redefining the AMER ICAN WELFARE STATE 341 (2001). For a fuller explication of the concept of the "undeserving poor," see KATZ, THE UNDESERVING POOR, supra note 8. For a slightly different approach, focusing on the connection between poverty and work, see HANDLER \& HASENFELD, WE THE POOR PEOPLE, supra note 8.

38. On the idea of expressivism, with examples of arguments that certain ways of talking about an issue can distort our understanding of that issue, see Jane $\mathrm{B}$. Baron, The Expressive Transparency of Property, 102 COLUM. L. REV. 208 (2002). 
far ${ }^{39}$ and it leaves them vulnerable to changes in public perception about how worthy they really are. ${ }^{40}$ While different ways of talking do not necessarily and on their own lead to different ways of thinking, ${ }^{41}$ it may be fruitful to abandon the individual/structural debate. ${ }^{42}$ And, as is developed below, talking in the old ways has had serious costs.

\section{HOMELESSNESS, POVERTY, AND RACE}

Over the past twenty years, advocates for the homeless have won some noteworthy victories, including more shelter beds (and better shelter conditions), more support for transitions from homelessness into housing, and a heightened appreciation of the coordination of efforts required to prevent the recently housed from falling back into homelessness. ${ }^{43}$ Yet large numbers of people remain homeless (or at least vulnerable to homelessness), ${ }^{44}$ and some municipalities have taken measures, such as passing ordinances barring aggressive panhandling or banning night time sleeping in public spaces, that advocates regard as directed against the homeless. ${ }^{45}$ One of Hopper's goals in Reckoning with Homelessness is to "chronicle[] the corrective strategies hatched by a nascent advocacy movement and the presentday predicaments that are their progeny" (p. 10). That is, he aims "to take retrospective measure of practical attempts to remedy and ethnographic efforts to document" (p. 14).

Hopper is not alone in seeking to assess the gains and losses of homeless advocacy over time. His counterparts in the legal community

39. See p. 194 (while the advocates told the stories of the homeless, "the ugly story on the street played on, stubbornly refusing to close out").

40. See Hafetz, supra note 4, at 1235 (describing an "angry backlash"); see also Maria Foscarinis, Downward Spiral: Homelessness and Its Criminalization, 14 YALE L. \& POL'Y REV. 1, 16-27 (1996) [hereinafter Foscarinis, Downward Spiral] (describing "anti-homeless" action s taken by cities).

41. See Baron, supra note 38 , at 229-35.

42. Hopper argues that in any event the "translation" of data - "the derivation of practical implications of research results, the distillation of core findings... the identification of specific relevancies to current policy deliberations" - should no longer be left to legislative aides or to attorneys. P. 212.

43. On shelter, see Callahan v. Carey and its aftermath, described supra note 35; on supportive transitions, especially for persons suffering from mental illness, see NAT'L INST. OF MENT Al He ALTh, Deinstitutionalization POLICY AND HOMELESSNESS: A REPORT TO CONGRESS (1990); on the need for "continuums of care," see U.S. DEP'T OF HOUSING and Urban Dev. Office of Policy Dev. and Research, Evaluations of CONTINUUMS OF CARE FOR HOMELESS PEOPLE (2002), available at www.huduser.org/ publications/pdf/continuums_of_care.pdf (last visited June 30, 2004). The McKinney Act provides for numerous programs and so must be considered another noteworthy victory. See Burt, Chronic Homelessness, supra note 10, at 1270-71. For a slightly different overview of successes gained, see Foscarin is, Homelessness and Human Rights, supra note 4, at 329-42.

44. See supra text accompanying note 31 .

45. See Foscarin is, Downward Spiral, supra note 40, at 16-26. 
have also sought to assay the overall success of their efforts in the courts and in the legislature. Hopper and his legal colleagues' assessments roughly converge on a single tone: regret. They also converge in their analysis of the missteps that have attended advocacy efforts to date. Three missteps are repeatedly cited: (1) the treatment of the homelessness problem as an emergency, warranting the kind of get-through-the-immediate-crisis response appropriate to natural disasters or traumatic injuries rather than long-term solutions; $(2)$ the failure to address the underlying structural causes of homelessness, such as the need for more affordable housing; and (3) the omission of issues pertaining to race in advocacy for the homeless. These three issues are clearly interrelated, with the first being a possible cause of the second, and the second being a possible cause of the third.

Hopper approaches the first problem, that of treating homelessness as a temporary emergency, largely in the context of Callahan v. Carey, the New York case brought to establish a right to shelter for indigent homeless men in New York City. ${ }^{46}$ Hopper is aware of the limits of the Callahan consent decree, noting especially the distracting attention to details that had to be "spelled out in obsessive fashion - space between beds, quality of food, ratio of men to toilet facilities, arrangements for storage of belongings." ${ }^{47}$ Still, Hopper sees some merit in the Callahan litigation strategy, the strength of which, he writes "lay in its simplicity: It established a floor below which public provision of shelter could not be allowed to fall" (p. 189). This floor has been useful, Hopper notes, in counteracting efforts by New York City officials to reduce the numbers of shelter beds and raise eligibility requirements even for those that remain (p. 189). And, relying on Martha Minow, he sees in the rights claims established by Callahan the "subversive potential [to] highlight a system's contingency and spur awareness of the gap between the shabby reality that is and the dimly glimpsed alternatives that might be."48

Hopper's overall conclusion, however, is measured: "[I]f the 1980 s taught us anything, it was that emergency relief was at best a necessary

46. See supra note 35 .

47. P. 186. A sample of the type of case to which Hopper refers includes Doe v. Dinkins, 600 N.Y.S.2d 939 (N.Y. App. Div. 1993) (holding that it was within the court's discretion to order various homeless shelters to cure fire code violations within ten days or stop accepting new arrivals); Lamboy v. Gross, 513 N.Y.S.2d 393 (N.Y. App. Div. 1987) (holding that homeless families cannot be housed at Emergency Assistance Unit offices that commonly do not have bathrooms, beds, and windows under any circumstance); Barnes v. Koch, 518 N.Y.S.2d 539 (N.Y. Sup. Ct. 1987) (holding that the city could not house pregnant women and families with children under age seven at a shelter that had potentially significant health threats); Wilkins v. Perales, 487 N.Y.S.2d 961 (N.Y. Sup. Ct. 1985) (holding that the Department of Social Services could waive the requirement that stated armories used as homeless shelters only house thirty people per room and 200 people total).

48. Pp. 188-89 (citing Martha Minow, Making All the Difference 307, 383 (1990)). 
stopgap measure. Shelter neither solves homelessness nor prevents further displacement" (p. 183). Hopper's legal colleagues fully concur. $^{49}$

For the legal advocates, the problem of erroneously treating homelessness as an emergency connects to the second advocacy misstep: ignoring the deeper causes of homelessness, such as lack of affordable housing and losses of jobs that pay decently. The argument here is, first, that advocating for more shelter did not itself solve the problem of housing for the poor, but also, second, that it affirmatively hampered the solution of the underlying problems that lead to homelessness. As Gary Blasi puts it:

[I]t is possible that the final record may suggest that advocacy aimed at ending homelessness actually prolonged it by diverting attention and resources from the wider issues of poverty and inequality .... Defining the problem as the problem of "the homeless" allows moderately liberal communities to "solve" the problem of extreme poverty and discrimination by reinventing the almshouse in the form of mass shelters. The creation of mass shelters, in turn, inevitably leads to an understandable "not in my backyard" ... reaction to these facilities, and equally inevitably, against "the homeless" who will inhabit them. ${ }^{50}$

Lucie White puts it this way:

The crisis of "homelessness" has not forged a new national commitment to make housing affordable for the poor. Nor has the crisis advanced the national discussion about how to finance and manage low-income housing on a wide scale.... And, with the new money that has been routed to "the homeless," new interests have sprung up. A growing sector of service providers and academic researchers are inevitably even if unintentionally - becoming invested in stabilizing "homelessness" as a permanent crisis, so their skills won't become obsolete, and their jobs won't go away. ${ }^{51}$

In other words, the attention to (emergency) shelter was a serious distraction, causing an irrevocable loss of resources that should have been devoted to (long-term) structural problems but were instead diverted into a new shelter "industry." 2

49. See, e.g., Foscarin is, Homelessness and Human Rights, supra note 4, at 332-33:

[W] here homelessness results from flood, hurricane or other natural disaster, and not from poverty, emergency solutions may be appropriate and effective. In those cases, once the sudden emergency is addressed, its victims are generally able to return to housing stability. Where the cause is poverty-related - such as inability to find affordable housing ... - then emergency shelter is not a sufficient solution to homelessness: once the emergency need is met, there is nowhere to go.

50. Blasi, And We Are Not Seen, supra note 2, at 569.

51. White, supra note 4, at 297-98.

52. See, e.g., White, supra note 4, at 300 ("'Homelessness' worked so well to mobilize public attention that little media space or citizen energy has remained available to address other housing issues."). For more on the costs of shelter remedies, see HOCH \& SLAYTON, supra note 30, at 232 (arguing that shelter facilities have been transformed into "long-term 
Hopper has a slightly different take on how advocacy efforts distracted attention from longer-term solutions. As he sees it, "the bulk of national advocacy efforts [was] deployed within the beltway," and amounted, in essence, to lobbying for programs (p. 196). Even where the efforts were "broad-based (e.g., supportive housing for persons with severe mental illness ...)" (p. 196), and even where they were successful, they contained a hidden trap. Advocates who obtained what they sought had to ensure that programs were renewed and funds reappropriated as expiration dates arrived; those advocates became "beholden to a growing constituency of programs dependent on federal funding" (p. 196). Advocacy was diverted, in other words, by the need to preserve its own gains.

On the other hand, Hopper basically agrees that the advocates made mistakes in their framing of the issue. "It would have been an act of constructive mischief," he writes, "to shift from a demand of passive resettlement ('more housing') to one of active reengagement ('give us a chance to work - and let us worry about a place to live')" (p. 197). And, like the lawyers, he is reflective about and critical of the unintended consequences of the methods through which he worked. Here, Hopper criticizes the naturalizing tendencies of his (and his colleagues') own ethnographies, which portrayed homelessness as "an exotic world, but one that has been safely domesticated; its protagonists, tantalizingly different from, yet plainly recognizable to, those of us secure at home" (p. 204).

The excitement of ethnography, Hopper explains, "lies... in redeeming the currency of actions and utterances whose face value would seem to be reckless, stupid, self-destructive, or crazy" (p. 209). But in showing that the homeless are not as odd or contemptible as they might seem, "causal analysis" of why they were on the streets in the first place was "scanted" (p. 205). The ethnographers took the homeless where they found them, without asking how they came to be there; in their accounts ("sheaves of thick description" (p. 212)), "disorder tends to be taken as a given, its genesis of secondary import to the task of capturing its manifold intricacies and plumbing its secrets" (p. 209; emphasis added). In structure, Hopper's self-critique strongly parallels those of the lawyers'; ultimately, rather than changing the status quo, the ethnographies, like the efforts to gain more shelter beds and palliative programs, entrenched the existing order. "Instead of the stubbornly abrasive substance we may have fancied ourselves as producing, the ethnographic product is readily accommodated as local color, prepackaged compassion, or reassuring narratives of resiliency on the margins" (p. 205).

caretaking institutions" in which the homeless are segregated in a way that "not only perversely sets them apart from other citizens but relegates them to the inferior status of worthy dependents"). 
Yet however deep the misgivings related to the first two missteps, nothing comes close to the regret and self-castigation expressed over the third misstep: the failure to take explicit account of race in dealing with homelessness. How could this have happened? On the legal side, the explanation usually begins with the observation that although the homeless are extremely poor and are increasingly members of minority groups, they have been portrayed in advocacy as a distinct category: "A frequent tactic of homeless rights lawyers has been to define homeless people as a separate, unique class that deserves society's utmost sympathy and support." 53

The reasons offered to explain the delineation of this new class of needy persons vary widely. On the more benign end, it has been suggested that the aim was to "distanc[e] modern images of homelessness from the dominant image of the past." 54 Another, relatively innocent, explanation is that the choice to identify with the cause of "homelessness" was made simply because "we could not see any better strategic option." Gary Blasi has argued that attitudes toward the homeless are embedded in cognitive networks that somehow render it "easier for people to identify with the harsh reality of homelessness than with that of mere poverty," to alter, those cognitive biases to avoid negative attitudes toward poverty and blacks. ${ }^{57}$ The most negative explanation asserts that images of the homeless as white (or at least, as not explicitly minority) are the product of "unconscious racism." 58

Whatever the explanation, the failure to deal with race has come at a price. For one thing, it has contributed to the separation between homeless-rights advocacy and poverty-law practice ${ }^{59}$ and thereby kept

53. Hafetz, supra note 4, at 1247; see also Blasi, And We Are Not Seen, supra note 2, at 566 (explaining that "the 'problem of homelessness' was constructed over time," and arguing that "there are important 'framing effects' (e.g., 'homelessness' vs. 'poverty') in public discourse").

54. Blasi, And We Are Not Seen, supra note 2, at 576; see also Daniels, supra note 4 (describing "shifting images" of the homeless, beginning with the derelict).

55. White, supra note 4, at 292; see also Blasi, And We Are Not Seen, supra note 2, at 567 ("Advocates were ... pragmatic: The focus on homelessness produced some results, whereas a diffuse focus on poverty seemed likely to produce nothing, particularly in the Reagan years.").

56. Blasi, And We Are Not Seen, supra note 2, at 567; see also Blasi, Social Policy and Social Science, supra note 6, at 209 ("[W]hereas it is difficult for most people to imagine the myriad detailed consequences of simply being very poor, it is easier for everyone to imagine being cold, being lost, being very far from - or without - a home.").

57. Blasi, Advocacy and Attribution, supra note 17, at 219-20; Blasi, And We Are Not Seen, supra note 2, at 576.

58. White, supra note 4, at 305-06 (citing Charles R. Lawrence III, The Id, the Ego, and Equal Protection: Reckoning with Unconscious Racism, 39 STAN. L. REV. 317 (1987)).

59. Hafetz, supra note 4, at 1247-48. 
homeless advocacy from achieving its potential to "bring[] together people whose initial interests were more narrowly focused on housing issues, welfare, education, and so on. ${ }^{" 60}$ But far more significant than the loss of strategic alliances is the way in which the absence of discussion of the connections between race and homelessness has affirmatively distorted understanding of the causes of the homelessness problem and of the depth of race discrimination in the U.S:

Poverty is implicated in homelessness not only in the present. Crosssectional and even longitudinal studies of homeless individuals fail to capture the fact that the myriad consequences of poverty and discrimination accumulate over time, over generations. The consequences of poverty and racism in the past are revealed in the present not only as poverty but also as poor educational attainment and limited skills, exhausted family resources and social networks, and so on. In the homelessness of today we see not only the interaction of today's poverty and today's personal decrements and disadvantages but also the consequences of poverty and discrimination long ago and long forgotten. ${ }^{61}$

The claim here is that even the "structural" account of homelessness is seriously incomplete and misleading because it does not explain the way past racial discrimination has affected the human capital and other resources available to a population which must now compete for ever-scarcer jobs and ever-less-affordable housing.

Hopper's chapter on "Homelessness and African American Men" is, remarkably, not an ethnography. Much of it is instead a chronicle of the omission of African Americans from other studies of homeless men. The rest of it is a rather heavy-handed survey of changes in the labor market, the black extended family, and the like that render black men more economically vulnerable and therefore more at risk of becoming homeless. Yet Hopper's conclusions about these "factors that account for the rise of homelessness among black males" (p. 157) are less interesting, and probably less important, than the larger framework in which he situates his discussion of race. Hopper's ethnographic work among the homeless - their survival methods and coping strategies - taught him that "people commonly arrive at shelters after having exhausted the resources of kin and family" (p. 155). If, as statistics showed, African American males were showing up at shelters in ever increasing numbers, ${ }^{62}$ then there was something to be learned about the networks on which they could no longer rely. In other words, the growth of black men as a percentage of the homeless should have drawn attention "to the routine, everyday strategies of

60. Blasi, Advocacy and Attribution, supra note 17, at 234.

61. Blasi, And We Are Not Seen, supra note 2, at 582.

62. P. 156 ("By the early 1980s, at least two-thirds of regular shelter users [in New York City] were African American. Nor was New York exceptional."). 
survival practiced in poor neighborhoods" and to the "community and kinship contexts of African American 'ghetto' life - its formations and flows under circumstances of concentrated poverty and residential segregation" (p. 149). But the opportunity was either not perceived or was ignored. Either way our understanding of the complexity of race is the poorer.

Again, Hopper's regret over the omission of race in the ethnography of homelessness echoes legal advocates' regret. Just as lawyers treated homeless persons as a distinct and unique class, so the ethnographers found in the homeless a conveniently "foreign" subject that could be studied like any other "exotic" population (p. 204). "The homelessness portrayed in these studies," Hopper observes, "tends to be sequestered, captive, estranged" (p. 204). But worse than the distortion in the picture of the homeless themselves was the failure to attend to the world from which they had emerged, a world deeply formed by race, but from which race had been sanitized. Our understanding of the way race works, inside and outside geographically African American neighborhoods, has suffered in consequence.

The sense of lost opportunity is palpable here, yet it is not entirely clear what, precisely, is being regretted. It would be one thing if more directly associating homelessness and race would have led to instrumental gains in the form, for example, of more litigation successes, but neither Hopper nor the legal advocates make such a claim. If anything, the argument sometimes flirts with, and sometimes explicitly asserts, the idea that the issue of race was avoided precisely because, given existing negative stereotypes, allowing it a role would have been poor strategy in the short term. ${ }^{63}$ The crux of the lament seems to be the failure to explore how, over time, the twinned forces of race and poverty combined to render blacks ever more susceptible to homelessness. ${ }^{64}$ Quite possibly such study might have fleshed out and supported what I earlier described as the vulnerability synthesis. Yet neither Hopper nor his colleagues even begin to explain why a thicker description of vulnerability would not have been treated in the same way as the thick descriptions of homeless persons' coping strategies. If the ethnographies' demonstration of the deeper order structuring the apparent chaos of life on the street led to complacency rather than outrage, why would a better understanding of the deep structure of vulnerability lead to anything different?

63. See supra text accompanying notes 56-58.

64. See Blasi, And We Are Not Seen, supra note 2, at 592 ("[W]e have nothing, on a purely metatheoretical level, equivalent to the computer models in population biology that capture both the structures of risk and incentive and the contours of individual vulnerability, revealing in simulation the nonobvious consequences of the interactions between the individual and the ecological."). 


\section{HOMELESSNESS AND WEALTH}

One of the reasons to analyze the errors of the past is to help answer the question, frequently asked in homeless advocacy, "where do we go from here"? ${ }^{65}$ Since Hopper's book is mostly backward looking, he makes relatively few suggestions. Some are fairly mainstream. He argues, for example, that we should abandon the model of "flood or famine relief" and the notion that homelessness is "a passing crisis [that] might be waited out" (p. 215-16). He also suggests further study of how housing problems were solved in the past, with an eye to identifying "those practices or policies [that] might be resurrected and retooled to the specifications of the present; and what newly fashioned remedies might be needed" (p. 215).

Others of Hopper's proposals depart from the standard fare. As we have seen, one of his critiques of the ethnographies of the homeless is that they made their subjects almost too accessible, too "normal"; if the people sleeping on streets or in the tunnels under Grand Central Station were coping quite well, then perhaps nothing needed to be done to aid them or to learn how they had come to live there to begin with. In short, Hopper writes, "the nuance, shading, and complexity that make for fine ethnography also compose an open invitation to willful misreading" (p. 212). To prevent such misreading, Hopper argues that ethnographers must more aggressively manage their own data: "This would mean taking seriously the translation process itself - the derivation of practical implications of research results, the distillation of core findings, the delineation of essential qualifiers of context or design, the identification of specific relevancies to current policy deliberations" (p. 212). No longer can these tasks be "left to legislative aides or jousting attorneys" (p. 212).

But perhaps Hopper's most provocative suggestion is one he makes almost in passing, and though I quoted it in the introduction to this Review, it is worth reading again:

It no longer suffices (if it ever did) to ask what it is about the homeless poor that accounts for their dispossession. One must also ask what it is about "the rest" of us that has learned to ignore, then tolerate, only to grow weary of, and now seeks to banish from sight the ugly evidence of a social order gone badly awry? (p. 214)

Hopper here seems to be saying that the ethnographers have been studying the wrong thing. Instead of capturing the "manifold intricacies" (p. 203) and the "shadowed details" (p. 212) of life on the streets and in shelters, they should have been studying the people who

65. See, e.g., O'FlAHERTY, supra note 20, at 275 (whose last chapter is entitled "What We Should Do"). 
passed the homeless by. The ethnographers studied the poorest of the poor, but maybe they should have been studying the rich.

In making this suggestion, Hopper cites his legal colleague Gary Blasi ${ }^{66}$ who has also argued that "if the underlying problem is how to end mass homelessness, then social scientists will have to focus less on homeless people and more on the people whose decisions (or acquiescence) result in the policies that produce homelessness. ${ }^{67}$ Blasi has repeatedly suggested that more attention be paid to how images of the homeless are created and processed, in order to understand "why average Americans are affected by images of homelessness, but not by images of extreme poverty." ${ }^{68}$ Part of Blasi's concern, as we have seen, is with the way in which failure to challenge attitudes about the homeless leave intact negative stereotypes about the remainder of the poor. ${ }^{69}$ A related concern, going forward, is with cognitive processes generally; the more advocates know about how people think, Blasi argues, the more they can "take account of attributional beliefs, and sometimes even shape them" in their own advocacy. ${ }^{70}$

If Hopper is correct in his conclusion that even the best ethnography of the homeless only contributes to their neglect, then surely it cannot hurt to turn to the "rest of us," and see what it is that allows us to walk past those less fortunate than ourselves. But, as poverty lawyers and welfare advocates remind us, attitudes toward poverty are deeply entrenched and almost impossible to dislodge. There is no harm, surely, in learning more about how we come to believe what we believe, and how to change beliefs. But we might just learn how fixed our beliefs are.

Still, it may be that Hopper and Blasi are on to something when they suggest that it is not poverty we need to study more, but wealth. Yet while they advocate what in essence would be a study of the wealthy, it may be that a study of people, rich or poor, is beside the point. Much of the social science research about homelessness has been about who the homeless are. But whoever the homeless may be - men, women, black, white, young, old, married, single - a defining aspect of their homelessness is what they have, or, more accurately,

66. Specifically, Blasi, Social Policy and Social Science, supra note 6. In that article, Blasi wrote: "This ... is a call for social scientists ... to look at the wider society and the elites who make social policy in this country." Id. at 216.

67. Blasi, And We Are Not Seen, supra note 2, at 583.

68. Blasi, Social Policy and Social Science, supra note 6, at 216.

69. See Blasi, Advocacy and Attribution, supra note 17, at 220.

70. Blasi, Advocacy and Attribution, supra note 17, at 233. Blasi's interest in understanding patterns of attribution overlaps recent work on the role of cognition in law and lawyering. See ANTHONY G. AMSTERDAM \& JEROME BRUNER, Minding THE LAw (2000); STEVEN L. WINTER, A ClEARING IN THE Forest: LAW, LifE, AND MIND (2001). For a critique of these works, see Dennis Patterson, Fashionable Nonsense, 81 TEXAS L. REV. 841 (2003). 
what they do not have. Poverty is not (just) a condition of persons; it is a condition of property holding. Let us call this condition "no property." When people have no property, it's hard to live the way "the rest of us" do.

"No property" is on one level remarkably simple: it's having nothing. And yet on another level, "no property" is hard to get hold of. As Jeremy Waldron has noted in his frequently cited Homelessness and the Issue of Freedom, ${ }^{71}$

One of the functions of property rules... is to provide a basis for determining who is allowed to be where.... One way of describing the plight of a homeless individual might be to say that there is no place governed by a private property rule where he is allowed to be. ${ }^{72}$

"No property" thus is a distinct legal condition of "no rights." Because the Supreme Court has held that wealth is not a suspect category for Fourteenth Amendment purposes, there is, for example, no right not to have no property ${ }^{74}$ Because the Court has also held that housing is not a fundamental right ${ }^{75}$ there is no right not to be homeless.

The legal condition of "no property" helps explain the otherwise mysterious strand of homelessness advocacy that has sought to vindicate rights to panhandle on subways ${ }^{76}$ to sleep in public parks at night, ${ }^{77}$ and to sit around idly in public libraries. ${ }^{78} \mathrm{I}$ am not the first to

71. Waldron, supra note 11.

72. Id. at 296-99.

73. I loosely borrow here from Hohfeld's concept of "no-rights," see Wesley Newcomb Hohfeld, Some Fundamental Legal Conceptions as Applied in Judicial Reasoning, 23 YALE L.J. 16 (1913), but my focus is less on the relationship between the homeless and others (which is what Hopper and Blasi wish to study) than on the material position in which "no property" places the homeless.

74. San Antonio Indep. Sch. Dist. v. Rodriguez, 411 U.S. 1 (1973).

75. Lindsey v. Normet, 405 U.S. 56 (1972). On the subsequent interpretation of Lindsey in the lower courts, see Ann M. Burkhart, The Constitutional Underpinnings of Homelessness, 40 HOUS. L. REV. 211, 211-12 (2003).

76. McFarlin v. District of Columbia, 681 A.2d 440 (D.C. 1996) (holding that a law banning aggressive panhandling, and all panhandling on the Metro and within fifteen feet of Metro stops was constitutional). But see Young v. New York City Transit Auth., 903 F.2d 146 (2d Cir. 1990), cert. denied, 498 U.S. 984 (1990) (holding that the homeless do not have a right to panhandle on the New York City subway system).

77. Pottinger v. City of Miami, 810 F. Supp. 1551 (S.D. Fla. 1992) (holding that it is unconstitutional to arrest homeless persons for sleeping, standing, and congregating in public). But see Davison v. City of Tucson, 924 F. Supp. 989 (D. Ariz. 1996) (specifically rejecting the holding in Pottinger).

78. Kreimer v. Bureau of Police, 958 F.2d 1242 (3d Cir. 1992) (holding that rules promulgated to discourage homeless patrons from staying in the library when not engaged in traditional library functions are constitutional). But see Armstrong v. District of Columbia Pub. Library, 154 F. Supp. 2d 67 (D.D.C. 2001) (holding that library rules that allowed guards to eject apparent vagrants were unconstitutionally vague and overbroad). 
note that victories in these areas - and there have been only a few ${ }^{79}$ - provide the homeless only with the right to be homeless effectively. ${ }^{80}$ But if you have no property, and no affirmative legal claim to have property, what else can you seek?

It is hard to describe a negative, and therefore "no property" remains elusive as a concept and a category. We can, however, seek to study what "no property" is a lack of. We can, in other words, study wealth, concentrating not only on what it buys those who have it, but what its absence would signify. In this sense, I think that Hopper and Blasi point in the right direction. Probably we can understand "no property" only by studying what it is a negative of. This is the paradox, then: we may only be able to understand poverty by understanding wealth.

\section{CONCLUSION}

Homelessness is not a new phenomenon, ${ }^{81}$ and homelessness may be a problem that will never disappear. ${ }^{82}$ But, as Hopper teaches in Reckoning With Homelessness, we don't have to give up on the problem, even if past legal and anthropological efforts have failed or have even made the problem worse. Echoing legal advocates, Hopper proposes that we study what it is about the wealthy that permits them to tolerate and accept homelessness - a new ethnography of the wealthy. There is no reason not to try. I propose here one other approach, which is to think about the homeless not in terms of who they are but instead in terms of what they have. It is worth considering the legal situation that arises out of "no property."

79. See, e.g., Loper v. New York Police Dep't, 999 F.2d 699 (2d Cir. 1993) (holding unconstitutional a law prohibiting all loitering in New York for the purpose of panhandling); Justin v. City of Los Angeles, 2000 WL 1808426 (C.D. Cal. Dec. 5, 2000) (issuing a temporary restraining order to stop the city from harassing homeless by constantly stopping and questioning them in order to drive them out of the skid row area of town); Pottinger v. City of Miami, 810 F. Supp. 1551 (S.D. Fla. 1992) (holding unconstitutional practices instituted to stop the homeless from sleeping, standing, and congregating in public); Orozco v. Sobol, 703 F. Supp. 1113 (S.D.N.Y. 1989) (holding that a homeless child has a right to attend public school even if she could not prove place of residency). But see Chad v. City of Fort Lauderdale, 66 F. Supp. 2d 1242 (N.D. Fla. 1998) (holding a city ordinance that prohibited begging on the beach and adjacent sidewalk to be a content neutral time/place/manner restriction); McFarlin v. District of Columbia, 681 A.2d 440 (D.C. 1996) (upholding as constitutional a law banning aggressive panhandling, and all panhandling on the Metro and within fifteen feet of Metro stops).

80. See, e.g., Daniels, supra note 4, at 729 ("Even when criminalization lawsuits are successful, the rights established are negative rights, in that at most they restrict ways in which government can punish homeless people for engaging in certain types of behavior, such as begging or living in public.").

81. KUSMER, supra note 12.

82. See Ellickson, supra note 21. 